University of Nebraska - Lincoln

DigitalCommons@University of Nebraska - Lincoln

2009

\title{
A modified Advection-Aridity model of evapotranspiration
}

\author{
Jozsef Szilagyi \\ University of Nebraska-Lincoln, jszilagyi1@unl.edu \\ Michael T. Hobbins \\ Australian National University \\ Janos Jozsa \\ Budapest University of Technology and Economics
}

Follow this and additional works at: https://digitalcommons.unl.edu/natrespapers

Part of the Natural Resources and Conservation Commons, Natural Resources Management and Policy Commons, and the Other Environmental Sciences Commons

Szilagyi, Jozsef; Hobbins, Michael T.; and Jozsa, Janos, "A modified Advection-Aridity model of evapotranspiration" (2009). Papers in Natural Resources. 895.

https://digitalcommons.unl.edu/natrespapers/895

This Article is brought to you for free and open access by the Natural Resources, School of at DigitalCommons@University of Nebraska - Lincoln. It has been accepted for inclusion in Papers in Natural Resources by an authorized administrator of DigitalCommons@University of Nebraska - Lincoln. 


\title{
Modified Advection-Aridity Model of Evapotranspiration
}

\author{
Jozsef Szilagyi'; Michael T. Hobbins²; and Janos Jozsa ${ }^{3}$
}

\begin{abstract}
The original and modified versions of the advection-aridity (AA) model of regional evapotranspiration are tested with data from the Solar and Meteorological Surface Observation Network (SAMSON). The resulting long-term mean annual evapotranspiration estimates are validated against water balances of 25 watersheds that are minimally affected by human activity and contain at least one SAMSON station, as well as with similar closures of SAMSON-station/gridded precipitation and runoff. In general, model performance is very similar among the two versions, explaining at least $80 \%$ of the spatial variance in the long-term means, simultaneously remaining well within $10 \%$ of the water balance-based values in their station-averaged long-term mean annual evapotranspiration estimates. The modified AA model, however, can be used in humid as well as in arid regions with the same set of calibrated parameters, whereas the original AA model may require a recalibration.
\end{abstract}

DOI: 10.1061/(ASCE)HE.1943-5584.0000026

CE Database subject headings: Evapotranspiration; Evaporation; Surface water; Water balance.

\section{Advection-Aridity Model and its Modification}

Brutsaert and Stricker (1979) proposed the advection-aridity (AA) model of regional evapotranspiration based on Bouchet's (1963) complementary relationship (CR), which expresses actual evapotranspiration $(E)$ as a combination of the wet environment $\left(E_{w}\right)$ and potential evapotranspiration $\left(E_{p}\right)$, or

$$
E=2 E_{w}-E_{p}
$$

The CR assumes constant energy availability $\left(Q_{n}\right)$ for sensible and latent heat fluxes at the evaporating surface. Because $E_{p}$ is often related to the evaporation rate of an evaporation pan and because the underlying physical processes are the same (i.e., a phase change from liquid to vapor), whether the source is an open water surface or the stomata of plants, the above-mentioned terms are henceforth referred to by dropping the transpiration reference (Brutsaert 1982). In the AA $E_{w}$ is estimated by the PriestleyTaylor (1972) equation

$$
E_{w}=\alpha Q_{n} \delta /(\delta+\gamma)
$$

where $\gamma=$ psychrometric constant; $\delta=$ slope of the saturation vapor pressure curve at actual air temperature $\left(T_{a}\right)$; and the parameter $\alpha$ typically lies in the range $1.1-1.4 . E_{p}\left(\mathrm{~mm} \mathrm{day}^{-1}\right)$ in

\footnotetext{
${ }^{1}$ Professor, Dept. of Hydraulic and Water Resources Engineering, Budapest Univ. of Technology and Economics, H-1111 Muegyetem Rkp. 3., Budapest, Hungary; and, Research Hydrologist, School of Natural Resources, Univ. of Nebraska-Lincoln, 625 Hardin Hall, 3310 Holdrege St., Lincoln, NE 68583. E-mail: jszilagyi1@unl.edu

${ }^{2}$ Research Associate, Environmental Biology Group, Research School of Biological Sciences, Australian National Univ., Canberra, ACT 0200, Australia.

${ }^{3}$ Chair, Professor, Dept. of Hydraulic and Water Resources Engineering, Budapest Univ. of Technology and Economics, H-1111 Muegyetem Rkp. 3., Budapest, Hungary.

Note. This manuscript was submitted on May 15, 2008; approved on September 15, 2008; published online on May 15, 2009. Discussion period open until November 1, 2009; separate discussions must be submitted for individual papers. This paper is part of the Journal of Hydrologic Engineering, Vol. 14, No. 6, June 1, 2009. CASCE, ISSN 1084-0699/ 2009/6-569-574/\$25.00.
}

AA is defined by the Penman (1948) equation as

$$
E_{p}=Q_{n} \delta /(\delta+\gamma)+f(u)\left(e^{*}-e\right) \gamma /(\delta+\gamma)
$$

where $e$ and $e^{*}=$ actual and saturation vapor pressure, respectively, with the latter taken at $T_{a}$ and $f(u)=$ wind function traditionally specified as

$$
f(u)=0.26\left(1+0.54 u_{2}\right)
$$

with $u_{2}$ being the mean horizontal wind speed at $2 \mathrm{~m}$ above the ground. The empirical constants require that the wind speed be given in meters per second, vapor pressure in $\mathrm{hPa}\left(10^{2} \mathrm{~Pa}\right)$, and $Q_{n}$ in water equivalent millimeters per day. Because the Penman equation works with daily average values, the $Q_{n}$ can be taken as the net energy, $R_{n}$, for the day.

Kahler and Brutsaert (2006) extended the AA to use class-A pan evaporation rates for $E_{p}$, rewriting the $\mathrm{CR}$ as

$$
E=(1+1 / b) E_{w}-E_{p} / b \text { or } E_{p}-E_{w}=b\left(E_{w}-E\right)
$$

where $b=$ empirically derived constant correction factor. Szilagyi (2007) suggested a temperature-dependent expression for $b$ such as $b=c \delta / \gamma$, where $c=$ another empirical constant. The advantage of the latter expression is that the likely spatial and/or seasonal variance in $b$ is accounted for by the $\delta / \gamma$ term, leaving the $c$ value to vary much less than $b$, therefore raising the possibility of finding a regionally or globally representative constant value of it. The CR from Eq. (5) is typically symmetric $(b=1)$ around $E_{w}$ with the Penman-estimated $E_{p}$ values and becomes asymmetric $(b \neq 1)$ when an "enhanced" potential evaporation measure, such as a class-A pan evaporation value, is employed for $E_{p}$. Although Brutsaert (2005) calls any potential evaporation estimates, such as the Penman equation or class-A pan evaporation rates, that rely on measurements from nonpotential environmental conditions (i.e., water availability is limited) "apparent," it may be practical to further distinguish between the two. The difference between the two types of apparent $E_{p}$ is caused by additional energy exchanges across the fixed boundary (i.e., the side and bottom of the class-A evaporation pan) of the enhanced potential evaporation source transferred by hot air forming over the land surface and by direct sunshine (Brutsaert and Parlange 1998). This additional energy exchange is significantly limited for sunken pans and natu- 
ral open water bodies, such as lakes and reservoirs. Thus, as the Penman equation was calibrated by sunken pan data and validated against small reservoir evaporation measurements (Penman 1948), it not only yields typically smaller evaporation rates than class-A pans, but it also makes Eq. (5) symmetric. That is why Szilagyi and Jozsa (2008) named the Penman values a "true" potential evaporation measure.

Based also on the CR, Morton (1983) developed a model of regional evaporation estimation, called WREVAP (Morton et al. 1985). In a comparison of the AA and WREVAP model estimates, employing standard meteorological data for 1961-1990 of the Solar and Meteorological Surface Observation Network (SAMSON), Szilagyi and Jozsa (2008) noted that the former yielded significantly larger evaporation estimates in the more arid western United States, as $E_{w}$ is obtained by evaluating $\delta$ at the actual (i.e., dry environment) air temperature, $T_{a}$, and not with the so-called equilibrium temperature $\left(T_{e}\right)$ the environment would achieve had it become completely wet at a regional scale.

Based on arguments in Morton (1983) and Szilagyi (2001) that the so-called equilibrium or wet environment surface temperature, $T_{e}$, remains unchanged during the drying of the environment under constant $Q_{n}$ - Szilagyi and Jozsa (2008) suggested obtaining $T_{e}$ by writing the Bowen ratio for a sunken pan (or a small shallow lake) as $H / E=\left(Q_{n}-E_{p}\right) / E_{p}$, which, employing measurements at two elevations and after rearrangement, yields

$$
Q_{n} / E_{p}=1+\gamma\left(T_{e}-T_{a}\right) /\left(e^{*}-e_{a}\right)
$$

where the saturation vapor pressure is evaluated at the desired $T_{e}$, and $E_{p}$ is from the Penman equation (where $T_{a}$ must be used). This switch from $T_{a}$ to $T_{e}$ in the modified AA model affects not only $E_{w}$, but also the temperature-dependent form of $b$. Taking $\alpha=1.31, c=1$, and evaluating $b$ and $E_{w}$ at $T_{e}$ (Szilagyi and Jozsa 2008) yielded an excellent agreement $\left(R^{2}=0.97\right)$ between the long-term mean annual $E$ estimates of the two models (i.e., $E^{\mathrm{mA}}$ from the modified AA model and $E^{W}$ from WREVAP) using the $E_{p}$ estimates, $E_{p}^{W}$, of WREVAP at the 210 SAMSON stations. Monthly $E_{p}^{W}$ was found to be a good estimator of class-A pan rates (Szilagyi and Jozsa 2008), and this way can be considered as an enhanced potential evaporation value. Szilagyi and Jozsa (2008) concluded that for long-term mean $E$ rates the two models yield practically identical estimates with the same (enhanced) potential evaporation values therefore the $E^{W}$ estimates will not be shown separately in the following. Substitution of $E_{p}^{W}$ for class-A pan evaporation is further justified because there are only 19 SAMSON stations with class-A pans and even those pans yield data only for the growing season (May-September) with many existing gaps. Note that the AA model is more versatile than WREVAP because it can use both types of $E_{p}$ : (1) that measured by a class-A pan or specified by $E_{p}^{W}$ and (2) potential evaporation rates provided by the Penman equation.

From now on the AA model is referred to as original, when $\delta$ in Eq. (2) is evaluated at the actual air temperature. (see Table 1.)

\section{Validation of the Modified AA Model with Water-Balance Closure Results}

Szilagyi and Jozsa (2008) employed the $E^{W}$ values in their AA model tests on the premise that the former yields a fairly good estimator of the regional evaporation rate as Morton (1983) had claimed, an assertion supported by Hobbins et al. (2001b). How-
Table 1. Summary of Different Evaporation Terms Used in Text

\begin{tabular}{ll}
\hline Notation & \multicolumn{1}{c}{ Variable } \\
\hline$E$ & Actual evaporation \\
$E_{p}$ & Potential evaporation \\
$E_{w}$ & Wet-environment evaporation \\
$E^{A}$ & Actual evaporation estimated by the original AA \\
& model \\
$E^{\mathrm{mA}}$ & Actual evaporation estimated by the modified AA \\
& model \\
$E^{\text {cell }}$ & Actual evaporation estimated by water balance \\
& closure of gridded precipitation and runoff \\
$E^{W}$ & Actual evaporation estimated by the WREVAP model \\
$E^{\mathrm{wb}}$ & Watershed-representative actual evaporation of \\
& minimally disturbed catchments estimated by water \\
$E_{p}^{W}$ & balance closure \\
& Potential evaporation estimated by the WREVAP \\
\hline
\end{tabular}

Note: Type of the evaporation term (whether it is actual, potential, or wet-environment value) is always denoted by a subscript and the method used in the derivation by a superscript.

ever, it is also possible to validate the modified AA model estimates of $E$ by water balance closure results on a long-term average basis.

From the 120 watersheds minimally disturbed by human activity (Wallis et al. 1991; Slack and Landwehr 1992) that were studied by Ramirez and Claessens (1994) and Hobbins et al. (2001a,b), the 25 that contained at least one SAMSON station (Fig. 1) within their boundaries were selected. (Two catchments contained two stations.) These stations and watersheds are shown in Fig. 1. For these watersheds runoff $(R)$ data for 1961-1990 were collected from the U.S. Geological Survey gauging stations, and precipitation $(P)$ data for the same period were gathered from the parameter-elevation regressions on independent slopes model (PRISM; Daly et al. 1994) at a 4-km grid resolution. In order to increase the number of data points, water-balance closure of $\langle P\rangle$ $-R$ was performed on a 10 -year basis, thus yielding $3 \times 27=81$

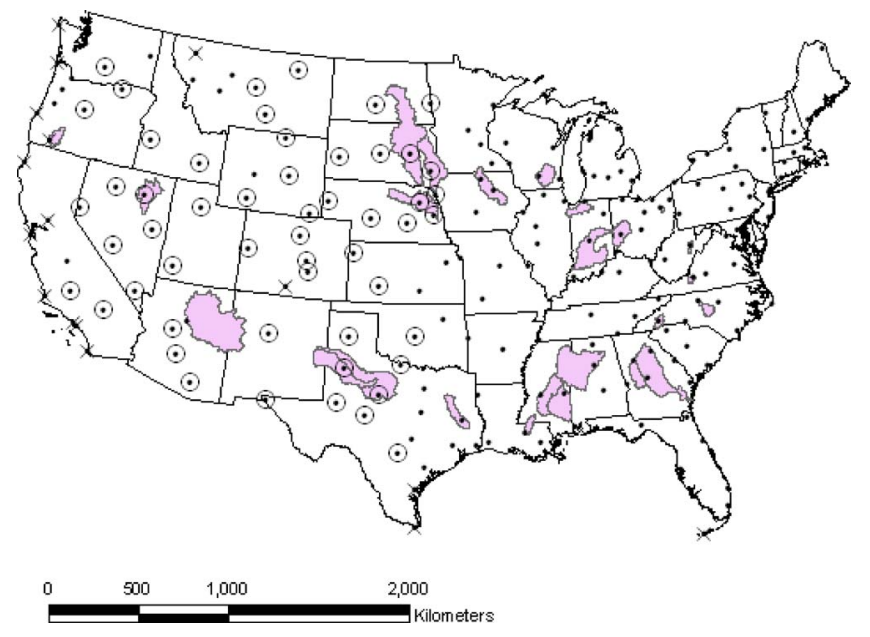

Fig. 1. Location of the 210 SAMSON stations as well as the 25 watersheds that contain a SAMSON station. Sixteen stations marked by a cross were omitted from the cell-based water-balance closure analysis. The 53 circled stations were considered semiarid or arid because the Wolock $(2003 \mathrm{a}, \mathrm{b})$ runoff value is less than $100 \mathrm{~mm}$ year $^{-1}$ for these locations. 

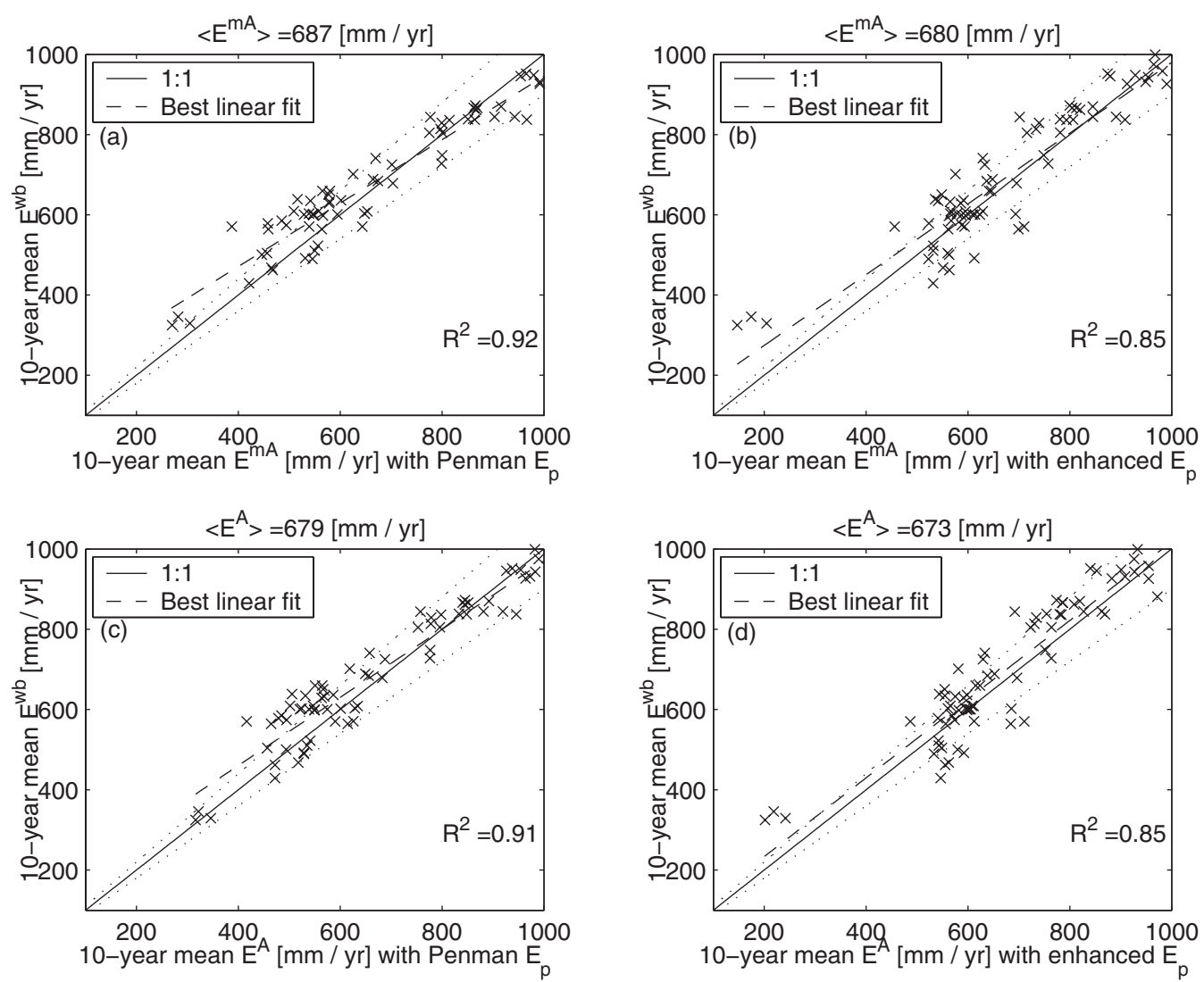

Fig. 2. Regression plots of water balance closure $\left(E^{\mathrm{wb}}\right)$ and the $\mathrm{AA}$ model $\left(E^{\mathrm{mA}}\right.$ : modified, $E^{A}$ : original model value) estimates of mean annual evaporation by watershed-station pairs. The sharp brackets denote the station-averaged long-term mean value. A point falls within the dotted lines provided water-balance and model-derived estimates differ less than $10 \%$. $\left\langle E^{\mathrm{wb}}\right\rangle=697 \mathrm{~mm}^{\mathrm{year}}{ }^{-1}$.

$E^{\mathrm{wb}}$ values to compare to the $E^{A}$ and $E^{\mathrm{mA}}$ estimates at the 27 SAMSON stations. Braces here denote spatial averaging of grid precipitation values over the watershed. A 10-year period is considered long enough that water storage changes can be neglected, but short enough to still see some variation among consecutive periods (as demonstrated in Fig. 2 by the smallest three values in each panel belonging to the same station but to different periods).

Input variables of the original (i.e., $b=1$ when $E_{p}$ is defined by the Penman equation, or $b>1$ with enhanced $E_{p}$ values) and modified (i.e., $b=1$ when $E_{p}$ is defined by the Penman equation and $E_{w}$ is evaluated at $T_{e}$, or $b=c \delta / \gamma$ with enhanced $E_{p}$ values when both $E_{w}$ and $\delta$ are evaluated at $T_{e}$ ) versions of the AA model were calculated with daily values of air and dew point temperatures, pressure, wind velocity, and incident global radiation. The routines of WREVAP were used to convert global radiation into net radiation $\left(R_{n}\right)$ values, as well as to obtain enhanced $E_{p}$ rates. As expected (Morton et al. 1985), WREVAP had problems with estimating daily enhanced $E_{p}$, so its enhanced $E_{p}$ rates were obtained on a monthly basis instead. In order to be consistent with the two types of $E_{p}$ (i.e., whether by the Penman equation or by WREVAP) the AA model's daily $E_{w}$ and $E_{p}$ rates were aggregated into monthly values before $E$ was calculated.

About 90\% (92 and 85\%, respectively) of the spatial (and to a much lesser degree temporal variation, due to the three 10-year periods for each station) variation expressed by mean annual $E^{\mathrm{wb}}$ can be explained by the modified AA model [Figs. 2(a and b)] having $\alpha=1.31$ and/or $c=1$. Two stations, Flagstaff, Ariz. and Medford, Ore. were omitted in Fig. 2 because at these stations both the modified and original AA-model versions significantly overestimate mean annual $E^{\mathrm{wb}}$. Of the 25 watersheds, these two expressed by far the largest variation in elevation. Being both stations in a basin surrounded by mountains, it is very likely that the wind speed values obtained at these SAMSON stations significantly underestimate the wind speed conditions at higher elevations. As a consequence, watershed representative $E_{p}$ is underestimated by the Penman equation, and therefore $E\left(=2 E_{w}-E_{p}\right)$ overestimated by the same degree. Station-averaged $E$ estimates of the modified AA model stayed within $5 \%$ of the similar $E^{\mathrm{wb}}$ value of $697 \mathrm{~mm}$ year $^{-1}$. The modified AA model's absolute error in the 10-year averages is less than $10 \%$ in about $67 \%$ of the stations.

Almost exactly the previous can be stated for the evaporation estimates of the original AA model [Figs. 2(c and d)] having previously optimized values $\alpha=1.28$ and $b=1.82$ from a comparison with WREVAP estimates (Szilagyi and Jozsa 2008), so the two versions (original and modified) perform very similarly for the selected watersheds which overall represent (due to their spatial distribution) a mildly humid environment.

This spatial distribution of the catchments (Fig. 1) is unfavorable for a comparison of the original and modified AA models' $E$ estimates in semiarid or arid regions having only nine catchments west of the 95th meridian, two of which (Flagstaff and Medford) contain SAMSON stations with likely underrepresentative wind measurements of the catchment conditions. Note the 95th meridian roughly coincides with the eastern border of Kansas and Oklahoma. As an alternative, the 1-km gridded mean annual recharge $(G)$ and base-flow-index $(B)$ data of Wolock $(2003 a, b)$ for 19511980 were subsequently utilized for water balance closure of 


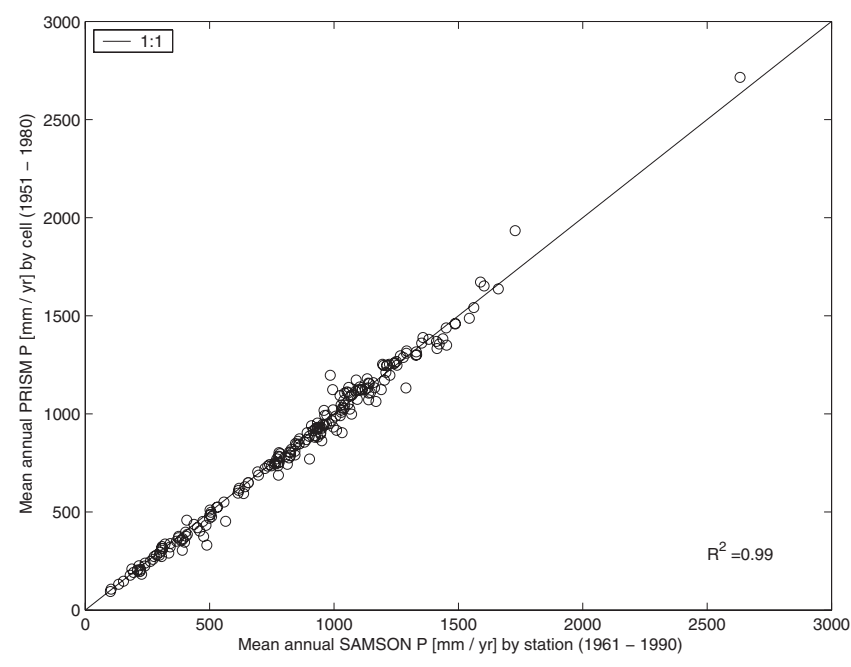

Fig. 3. Regression plot of mean annual precipitation $(P)$ values between SAMSON stations and PRISM cells containing the station

evaporation. $B$ is defined as the ratio of the mean annual values of $G$ and $R$, from which mean annual runoff, $R$, could be calculated for each grid. The PRISM data are also available for the same period enabling water balance closure of $E$ on a cell-wise basis. The temporal overlap of the Wolock $(2003 \mathrm{a}, \mathrm{b})$ data with the SAMSON one, however, is not perfect, having only 20 years (i.e., 1961-1980) in common. The analysis could not be restricted to this overlapping period only because the Wolock data contain period-averaged values unlike the hourly SAMSON or monthly PRISM data sets. At the same time a 30-year period is typically considered long-enough for obtaining fairly stable averages of climatic and hydrologic variables (Fig. 3), which makes the computed averages over the two overlapping 30 -year periods comparable so that a difference between mean annual values of $E^{A}$ or $E^{\mathrm{mA}}$ and $E^{\mathrm{wb}}$ can be regarded to be minimally affected by the difference in the averaging periods.

From the Wolock (2003a, b) and PRISM grids the 1- and 4-km cells that contained a SAMSON station were selected and the mean annual water balance closure $E^{\text {cell }}$ values computed. This computation however included the point precipitation values of the SAMSON stations as well, so that for each selected cell mean annual $P$ was obtained as the arithmetic average of the PRISM and SAMSON precipitation values. The current method of longterm mean annual $P$ calculation was chosen because (1) precipitation this way is estimated by data possibly (i.e., it could not be verified if a National Weather Station, employed by PRISM, was also designated as a SAMSON station or not) coming from different sources, in which case the two $P$ values can be considered as independent estimates of the true long-term mean $P$ value of the area; (2) SAMSON measurements, being point values and such considered to be more reliable than a spatially interpolated one, this way may correct to a certain degree for any possible systematic error in the PRISM values, whereas at the same time; and (3) spatially representative gridded values are preferable over the point measurements of the SAMSON stations, especially, because the $E$ values of the AA-model themselves are such spatially representative variables.

Fig. 1 marks the 16 SAMSON stations that were left out of the ensuing analysis presenting themselves as outliers in the regression plot of $E^{\text {cell }}$ versus $E$ values. Thirteen of them are coastal stations (including one that is not strictly a coastal station near Sacramento, Calif., where the moisture-laden "delta breeze" blowing from the San Francisco Bay area is a common occurrence) located near sudden discontinuities of atmospheric and surface properties. At these stations air humidity can easily become decoupled from the land soil moisture dynamics, where the predominantly westerly wind blowing from the sea leads to a small difference in $E_{p}$ and $E_{w}$ due to a depressed vapor pressure deficit causing an overestimation of actual $E$ by a large degree. Such decoupling may be present at other coastal stations as well, although to a probably lesser degree at the eastern sea board due to the relative positions of land and sea in relation to the westerly winds characteristic of midlatitudes, and therefore they do not show up as obvious outliers in the regression plots. The remaining three stations are all located in valley settings of highly varied topography. For Kalispell, Mont., with annual precipitation of $433 \mathrm{~mm}$, an $E^{\text {cell }}$ value of $47 \mathrm{~mm}$ year $^{-1}$ is an obvious underestimation of mean annual evaporation of the area. Again, Medford, Ore., with $P=526 \mathrm{~mm} \mathrm{year}^{-1}$, resulted in $E^{\text {cell }}=289 \mathrm{~mm} \mathrm{year}^{-1}$ versus the modified AA model's $E=657 \mathrm{~mm}$ year $^{-1}$ value, when employing Penman $E_{p}$. Comparing the two $E$ estimates to the watershed representative $E^{\mathrm{wb}}$ of $480 \mathrm{~mm}$ year $^{-1}$, one is clearly a significant underestimation, whereas the other, an overestimation of the area-representative mean annual evaporation rate. At Alamosa, Colo., with mean annual precipitation of a mere $179 \mathrm{~mm} \mathrm{year}^{-1}$, an $E^{\text {cell }}$ value of $122 \mathrm{~mm} \mathrm{year}^{-1}$ is certainly a realistic estimate. However, this is the station where all the different models (be it WREVAP, original, or modified AA models employing Penman or enhanced $E_{p}$ ) overestimate a realistic water balance closure by far the largest degree (up to 250\%) among the inland stations. Omission of this station from further analysis was decided due to the lack of site-specific station information that could explain model results (e.g., whether the station is affected by large scale irrigation projects-typical of the area-in the close vicinity) and guide one with choosing a proper correction in the models.

Fig. 4 displays the original $\left(\alpha=1.28\right.$ and $b=1.82$ with $E_{p}^{W}$ values) and modified ( $\alpha=1.31$ and $c=1$ with $E_{p}^{W}$ values) AA model estimates of $E$ plotted against cell water balance closures for the remaining 194 SAMSON stations. Again, overall performance is very similar between the two versions and whether Penman or enhanced $E_{p}$ is employed. More than $80 \%$ of the spatial variance in mean annual $E$ is explained by the model, whereas the stationaveraged $E$ estimates are well within $10 \%$ of the station-averaged closure value of $555 \mathrm{~mm}_{\text {year }}{ }^{-1}$. The largest difference between the two model versions can be observed for low $E$ values. The original AA model overestimates low evaporation rates, whereas the modified AA model does not.

Fig. 5 displays model estimates restricted to 53 arid or semiarid SAMSON stations, marked by open circles in Fig. 1. The following two criteria determined whether or not a station was considered arid/semiarid: (1) it had to lie west of the 95th meridian; and (2) the cell it belongs to had to have a Wolock (2003a, b) runoff value less than $100 \mathrm{~mm}_{\text {year }}{ }^{-1}$. Again, the extent of the spatial variance explained $\left(R^{2}\right)$ by the two versions of the AA model are similar, the modified version performing just slightly better. The difference, however, is significant in the stationaveraged $E$ estimates. The original AA model overestimates the station-averaged cell water balance closure of $356 \mathrm{~mm}^{-1} \mathrm{year}^{-1}$ by about 8 and $13 \%$, respectively, depending whether Penman or enhanced $E_{p}$ was used in the calculations. The modified version underestimates it by 3 and over by $6 \%$. Although for the original version the majority of the points lie to the right of the $1: 1$ line (meaning an overestimation), for the modified one they are about evenly distributed around it. This reconfirms the conclusion of 

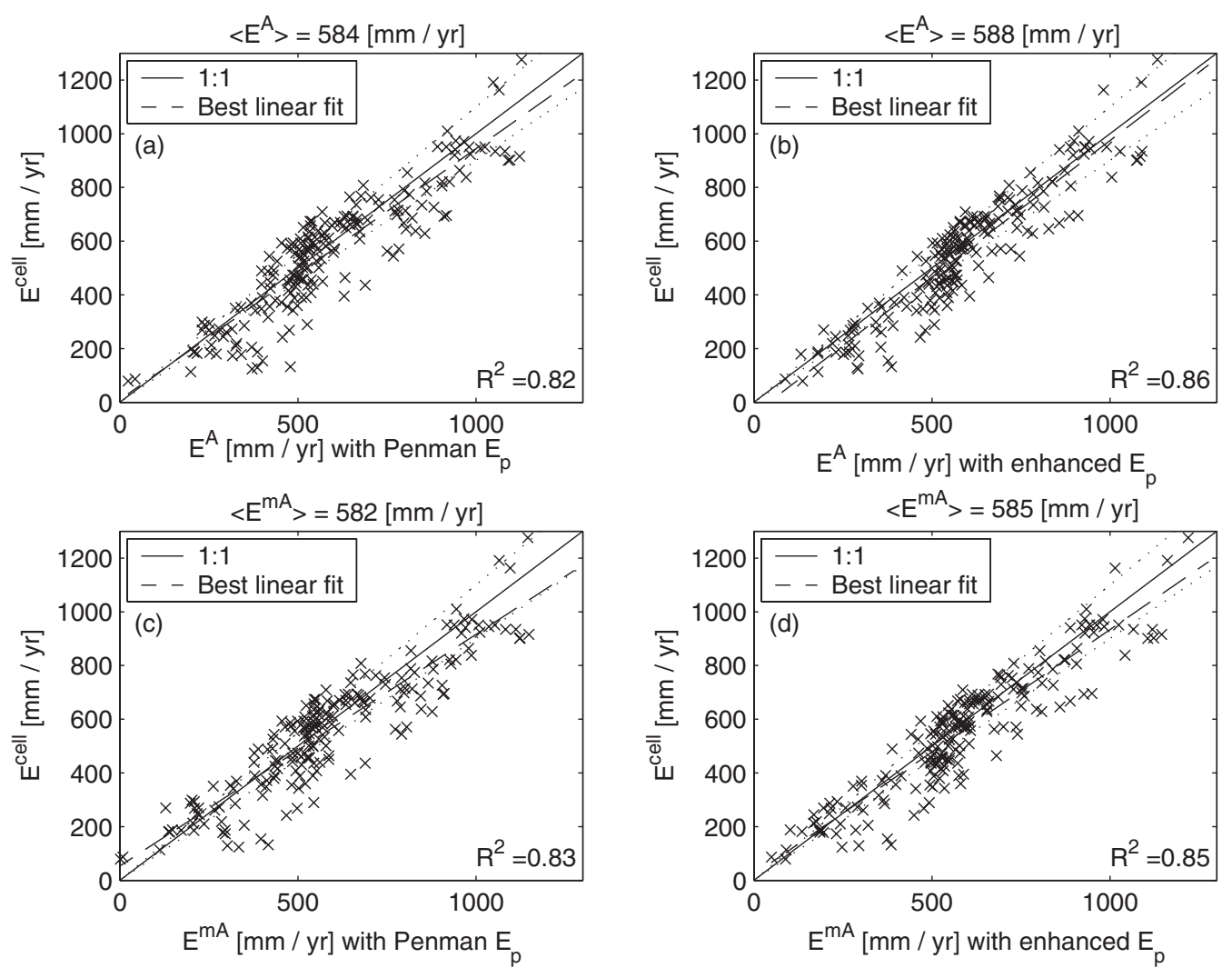

Fig. 4. Regression plots of the cell water balance closure $\left(E^{\text {cell }}\right)$ and original $\left(E^{A}\right)$, as well as modified AA $\left(E^{\mathrm{mA}}\right)$ model estimates of mean annual evaporation for the 194 SAMSON stations. The sharp brackets denote the station-averaged long-term mean value. A point falls within the dotted lines in the graphs provided $\left|E^{\text {cell }}-E\right|<10 \%$. $\left\langle E^{\text {cell }}\right\rangle=555 \mathrm{~mm} \mathrm{year}^{-1}$.
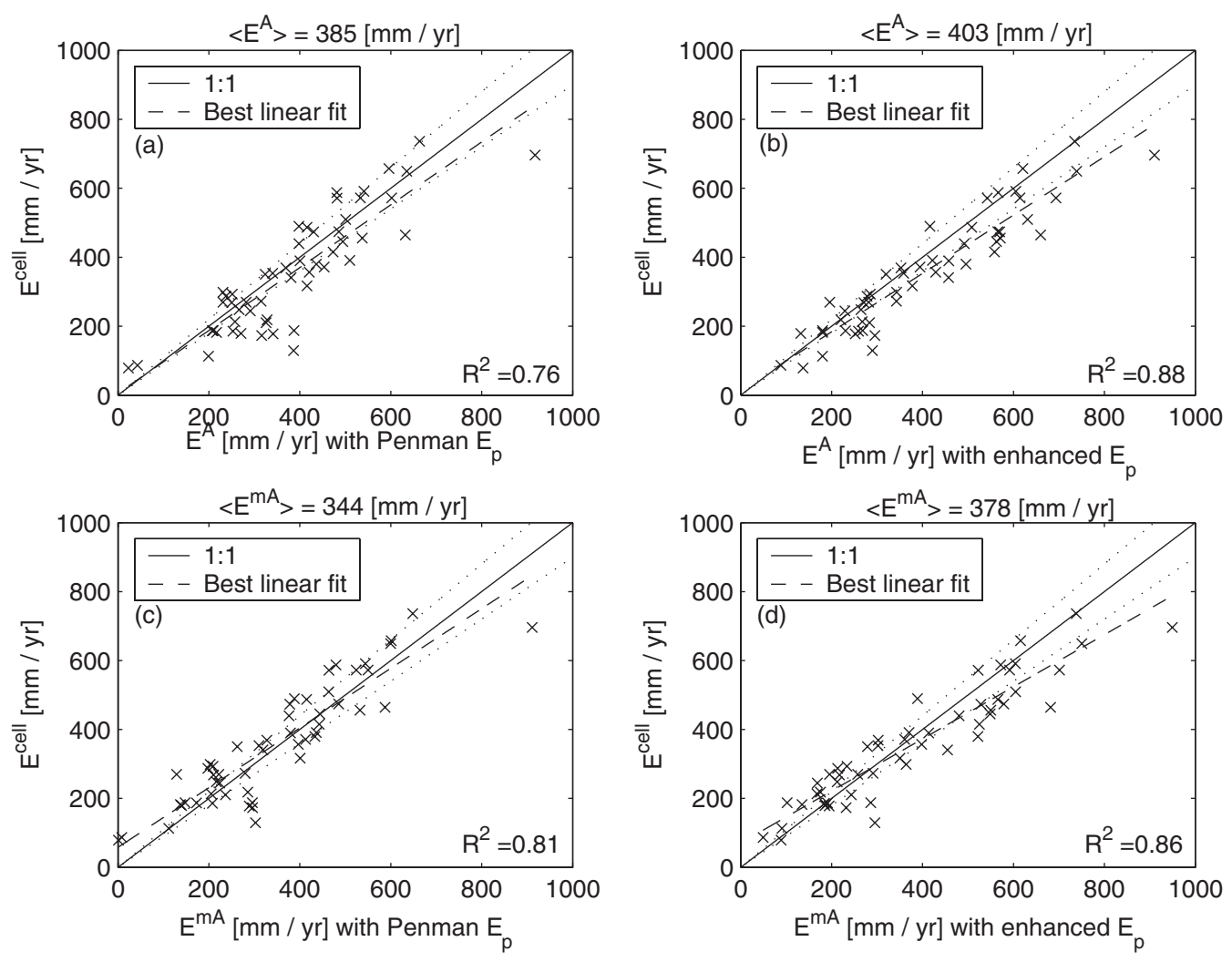

Fig. 5. Same as Fig. 4 but with the 53 semiarid SAMSON stations. $\left\langle E^{\text {cell }}\right\rangle=356 \mathrm{~mm}^{-1} \mathrm{ear}^{-1}$ 
Szilagyi and Jozsa (2008) who used $E^{W}$ estimates in place of the water balance closure values applied in this study that the original AA model tends to overestimate evaporation rates in semiarid or arid regions with its Priestley-Taylor parameter calibrated with data predominantly from humid watersheds.

\section{Summary and Conclusions}

A modified version of the original advection-aridity model of Brutsaert and Stricker (1979) has been tested using catchmentand cell-based water balances. Although the original and modified AA models yielded very similar evaporation estimates overall, the original AA model tended to overestimate cell-based water balance closure of evaporation in semiarid to arid regions, typically in the western part of the United States. This is because the original AA model employs the actual measured air temperature in the Priestley-Taylor (1972) equation of wet environment evaporation, whereas the modified version of the AA model accounts for the expected shift in temperatures (which may exceed $10^{\circ} \mathrm{C}$ in hot, arid regions) as the environment switches from a water limited to an energy-limited state (and vice versa) and employs an estimate of the wet environment surface temperature (Szilagyi and Jozsa 2008) in the Priestley-Taylor equation. The resulting lower rate of wet environment evaporation directly leads to a smaller value of the evaporation estimate in the complementary relationship employed by the AA model.

Consequently, the modified version of the AA model can be applied in both arid and humid regions with the same set $(\alpha$ and/or $c$ ) of the calibrated parameters, whereas the original version may require different values of the Priestley-Taylor $\alpha$ and/or the correction factor, $b$, (with enhanced potential evaporation values) depending on the aridity of the environment to maintain the same accuracy. So when one requires evaporation estimates over an area with widely varying humidity and temperature and does not want to or cannot perform site specific calibration, the modified version of the AA model can be an obvious choice over the traditional one. Otherwise, with careful site-specific calibration the two model versions are expected to perform very similarly.

\section{Acknowledgments}

This work has partially been supported by the European Union's Climate Change and Variability: Impact on Central and Eastern Europe (CLAVIER) FP6 project. The writers are grateful to the anonymous reviewers whose comments greatly improved the original version of the manuscript.

\section{References}

Bouchet, R. J. (1963). "Evapotranspiration reelle, evapotranspiration potentielle, et production agricole." Ann. Agron., 14, 743-824.
Brutsaert, W. (1982). Evaporation into the atmosphere: Theory, history and applications, D. Reidel, Dordrecht, The Netherlands.

Brutsaert, W. (2005). Hydrology: An introduction, Cambridge University Press, Cambridge, Mass.

Brutsaert, W., and Parlange, M. B. (1998). "Hydrologic cycle explains the evaporation paradox." Nature (London), 396(6706), 30.

Brutsaert, W., and Stricker, H. (1979). "An advection-aridity approach to estimate actual regional evapotranspiration." Water Resour. Res., 15(2), 443-449.

Daly, C., Neilson, R. P., and Phillips, D. L. (1994). "A statisticaltopographic model for mapping climatological precipitation over mountainous terrain." J. Appl. Meteorol., 33(2), 140-158.

Hobbins, M. T., Ramirez, J. A., and Brown, T. C. (2001a). "The complementary relationship in estimation of regional evapotranspiration: An enhanced advection-aridity model." Water Resour. Res., 37(5), 13891403.

Hobbins, M. T., Ramirez, J. A., Brown, T. C., and Claessens, L. H. J. M. (2001b). "The complementary relationship in estimation of regional evapotranspiration: The complementary relationship areal evaporation and advection-aridity models." Water Resour. Res., 37(5), 1367-1387.

Kahler, D. M., and Brutsaert, W. (2006). "Complementary relationship between daily evaporation in the environment and pan evaporation." Water Resour. Res., 42(5), W05413.

Morton, F. I. (1983). "Operational estimates of areal evapotranspiration and their significance to the science and practice of hydrology." $J$. Hydrol., 66(1), 1-76.

Morton, F. I., Ricard, F., and Fogarasi, S. (1985). "Operational estimates of areal evapotranspiration and lake evaporation-Program WREVAP." Paper No. 24, National Hydrology Research Institute, Ottawa.

Penman, H. L. (1948). "Natural evaporation from open water, bare soil, and grass." Proc. R. Soc. London, Ser. A, 193(1032), 120-146.

Priestley, C. H. B., and Taylor, R. J. (1972). "On the assessment of surface heat flux and evaporation using large-scale parameters." Mon. Weather Rev., 100(2), 81-92.

Ramirez, J. A., and Claessens, L. (1994). "Large scale water budgets for the United States." Final Progress Rep. Cooperation Agreement No. 27-C2-618, Hydrological Science and Engineering Dept., Colo. State Univ., Fort Collins, Colo.

Slack, J. R., and Landwehr, J. M. (1992). "Hydro-climatic data network (HCDN): A U.S. Geological Survey streamflow data set for the United States for the study of climate variations, 1874-1988." U.S. Geological Survey Open File Rep. No. 92-129, Washington, D.C.

Szilagyi, J. (2001). "On Bouchet's complementary hypothesis.” J. Hydrol., 246(1-4), 155-158.

Szilagyi, J. (2007). "On the inherent asymmetric nature of the complementary relationship of evaporation." Geophys. Res. Lett., 34(1), L02405.

Szilagyi, J., and Jozsa, J. (2008). "New findings about the complementary relationship-based evaporation estimation methods." J. Hydrol., 354(1-4), 171-186.

Wallis, J. R., Lettenmaier, D. P., and Wood, E. F. (1991). "A daily hydroclimatological data set for the continental United States." Water Resour. Res., 27(7), 1657-1663.

Wolock, D. M. (2003a). "Estimated mean annual natural ground-water recharge in the conterminous United States." U.S. Geological Survey Open-File Rep. No. 03-311, Washington, D.C., 〈http://water.usgs.gov/ lookup/getspatial?rech48grd $>$ (June 10, 2008).

Wolock, D. M. (2003b). "Flow characteristics at U.S. Geological Survey streamgages in the conterminous United States." U.S. Geological Survey Open-File Rep. No. 03-146, Washington, D.C., 〈http://water.usgs. gov/lookup/getspatial?bfi48grd (June 10, 2008). 